\title{
Analisis Sedimentasi Dan Prediksi Distribusi Sedimen Di Waduk Tilong Kabupaten Kupang
}

\author{
Ghozali Mahmud ${ }^{1}$, Suseno Darsono ${ }^{2}$, Thomas Triadi $\mathbf{P}^{3}$ \\ Magister Teknik Sipil, Fakultas Teknik, Universitas Diponegoro, Semarang ${ }^{1,2,3}$ \\ ghozalimahmud@student.undip.ac.id ${ }^{1}$,sdarsono@hotmail.com ${ }^{2}$, putranto@ft.undip.ac.id ${ }^{3}$ \\ DOI: http://dx.doi.org/10.31869/rtj.v3i2.1788
}

\begin{abstract}
Abstrak: Isu utama dalam pengelolaan waduk adalah permasalahan sedimentasi. Sedimentasi dapat berupa hasil dari proses erosi lahan pada Daerah Tangkapan Air (DTA) waduk maupun hasil dari longsoran tebing sungai atau tebing pada waduk itu sendiri. Waduk Tilong yang terletak di Desa Oelnasi Kabupaten Kupang Provinsi Nusa Tenggara Timur, merupakan salah satu waduk di Pulau Timor yang mengalami penurunan fungsi waduk akibat permasalahan sedimentasi. Penelitian ini bertujuan untuk menganalisis besaran volume sedimentasi yang terjadi selama kurun waktu 20022015 serta memprediksi pola distribusi sedimen yang mengendap di waduk dalam usaha pemeliharaan Waduk Tilong yang lebih optimal. Dari hasil penelitian ini, kurva lengkung kapasitas waduk hasil perhitungan distribusi sedimen berdasarkan survei bathimetri tahun 2015 akan dibandingkan dengan kurva lengkung kapasitas awal waduk tahun 2002. Analisis distribusi sedimen dalam penelitian ini menggunakan Empirical Area Reduction Method. Berdasarkan hasil penelitian, telah terjadi penurunan volume kapasitas waduk sebesar 3.060.231,99 m3 selama kurun waktu 2002-2015 dan ketinggian nol baru pada waduk adalah $+72,83 \mathrm{~m}$. Kapasitas volume total waduk Tilong yang pada tahun 2015 adalah sebesar 16,47 juta m3 sedangkan volume awal waduk di tahun 2002 adalah sebesar 19,07 juta m3 pada saat muka air normal.
\end{abstract}

Kata Kunci : Waduk Tilong, Sedimentasi Waduk, Distribusi Sedimen, Empirical Area Reduction Method

\section{PENDAHULUAN}

Waduk merupakan suatu wadah buatan yang digunakan untuk menampung air, limbah atau bahan cair lainnya yang terbentuk akibat dibangunnya suatu bendungan (Direktorat Jendral Sumber Daya Air, 2009). Sedimentasi waduk berasal dari erosi lahan dan sungai sepanjang pengalirannya yang terangkut sampai ke waduk dan akhirnya mengendap di dalam waduk. Faktor-faktor yang berperan dalam proses sedimentasi waduk adalah topografi, sistem/tata tanam, pola penggarapan lahan, pola penyebaran penduduk, curah hujan, dan jenis tanah (Wulandari, 2007). Sedimentasi secara nyata telah diketahui sebagai penyebab penurunan fungsi waduk. Salah satu waduk di Indonesia mengalami pengurangan volume waduk selama masa beroperasinya adalah waduk Cacaban di Kabupaten Tegal Provinsi Jawa Tengah. Selama 58 tahun tahun beroperasi, kapasitas volume waduk Cacaban telah berkurang sebesar $62 \%$ akibat laju sedimen yang masuk ke dalam tampungan waduk (WWS \& Sundari, 2016). Kapasitas tampungan secara bertahap akan berkurang diakibatkan akumulasi sedimen yang masuk ke dalam waduk yang berakibat terjadinya perubahan pada kurva luas dan volume tampungan waduk (Issa et al., 2016) yang pada akhirnya akan mempengaruhi kemampuan pelimpah dalam mengalirkan besaran bajir yang datang. Sedimen yang masuk ke dalam waduk akan mengendap pada setiap permukaan waduk. Pola distribusi sedimen di dalam waduk memiliki karakteristik yang berbeda untuk tiap waduk begantung kepada bentuk waduk, sistem operasi dan ukuran butiran sedimennya. Pola distribusi sedimen pada waduk berguna dalam memperkirakan volume efektif yang tersedia sepanjang umur efektif waduk.

Waduk Tilong terletak di Desa Oelnasi Kecamatan Kupang Tengah Kabupaten Kupang Provinsi Nusa Tenggara Timur. Bendungan ini dibangun pada tahun 19952001, dan secara geografis terletak pada koordinat $10^{\circ} 10^{\prime} 15,48^{\prime}$ ' LS dan $123^{\circ} 44^{\prime}$ 43,42" BT. Bendungan Tilong merupakan bendungan tipe urugan batu dengan inti tanah kedap air di tengah. Tinggi bendungan utama 44,5 $\mathrm{m}$ dan panjang $162 \mathrm{~m}$. Luas daerah aliran sungai sebesar $36,47 \mathrm{~km} 2$ dengan kapasitas tampungan total (tahun 2002) 19,07 juta $\mathrm{m}^{3}$ dan kapasitas tampungan efektif (tahun 2002)

\begin{tabular}{lll}
\hline ISSN 2599-2081 & Fakultas Teknik UMSB & 227
\end{tabular}

EISSN 2599-2090 
17,32 juta $\mathrm{m}^{3}$. Adapun manfaat dari Waduk Tilong adalah penyediaan air baku di Kota Kupang sebesar 150 liter/det dan penduduk di sekitar bendungan sebesar 2,5 liter/detik, penyediaan air untuk irigasi sebesar $1.484 \mathrm{ha}$, serta pengendalian banjir di hilir Sungai Tilong (Balai Wilayah Sungai Nusa Tenggara II, 2015).

Penelitian ini bertujuan untuk menganalisis besaran volume serta memprediksi pola distribusi sedimen yang mengendap di Waduk Tilong dalam usaha pemeliharaan waduk yang lebih optimal dalam upaya keberlanjutan fungsi Waduk Tilong. Dari hasil penelitian ini, lengkung kapasitas hasil perhitungan distribusi sedimen berdasarkan survei bathimetri tahun 2015 akan dibandingkan dengan lengkung kapasitas awal waduk.

\section{METODE PENELITIAN}

Pengumpulan Data Sekunder

Data yang digunakan dalam penelitian ini adalah sebagai berikut :

1. Data Teknis Bendungan Tilong.

2. Data hubungan elevasi-luas-tampungan awal (tahun 2002) Waduk Tilong.

3. Data hasil pengukuran echo sounding.

\section{Analisis Sedimentasi (Echo Sounding)}

Pengukuran sedimen pada Waduk Tilong digunakan dengan cara pengukuran elevasi dasar waduk saat selesai dibangun pada tahun 2002 dan membandingkan dengan perubahan dasar waduk pada tahun 2015. Perbedaan volume dari 2 echo sounding dari tahun yang berbeda menggambarkan sedimentasi yang terjadi. Pengukuran echo sounding dilakukan dengan beberapa cross yang melintang waduk dengan jarak tertentu. Gambar 1 memperlihatkan situasi waduk dengan penempatan cross yang dilakukan.

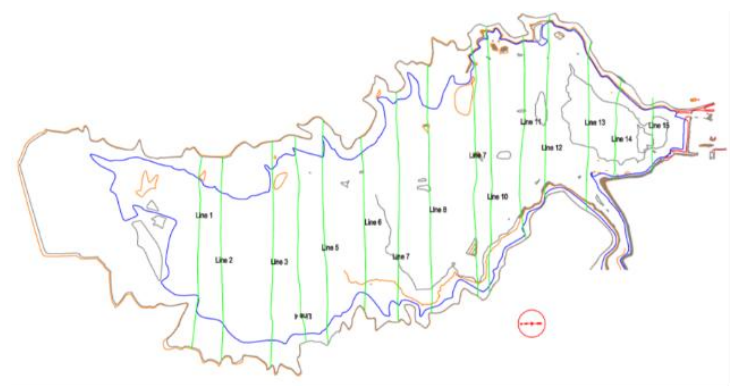

Gambar 1. Cross Section Waduk Tilong
Dari pengukuran penampang melintang Tahun 2015 dan kondisi eksisting tahun 2002 dihitung luasan polygon untuk masing-masing potongan. Selisih luasan kedua tahun pengukuran tersebut merupakan luasan sedimentasi pada potongan tersebut.

Volume sedimen dapat dihitung menggunakan pendekatan luas polygon diantara 2 cross section kemudian dikalikan dengan jarak antar cross-nya. Seperti pada Persamaan 1 berikut :

$V n=1 / 2 x(A n+A n+1)$

Dengan:

$\mathrm{V}_{\mathrm{n}} \quad$ : Volume antar cross ke- $\mathrm{n}\left(\mathrm{m}^{3}\right)$

$\Delta \mathrm{h} \quad$ : Jarak antar cross ke-n $(\mathrm{m})$

$A_{n+1} \quad$ : Luasan cross ke $n+1\left(m^{2}\right)$

$\mathrm{A}_{\mathrm{n}} \quad$ : Luasan cross ke-n $\left(\mathrm{m}^{2}\right)$

\section{Distribusi Sedimen di Waduk}

Analisis distribusi sedimen dalam penelitian ini menggunakan Metode Empiris Pengurangan Luas (Empirical Area Reduction Method), metode ini memiliki tingkat kesalahan yang relatif lebih kecil dibandingkan dengan metode empiris penambahan luas (Tukaram et al., 2016). Perbedaan antara dua metode tersebut adalah penggunaan tipe kurva untuk mendistribusikan sedimen. Pada dasarnya kedua metode tersebut dapat diselesaikan dengan langkah-langkah berikut ini (Morris \& Fan, 2010) :

1. Menentukan volume sedimen yang mengendap di waduk.

2. Memilih kurva untuk memplotkan titik hubungan antara nilai $\mathrm{F}$ dan kedalaman relatif (p). Tipe kurva ditentukan berdasarkan :

a. Bentuk waduk, ditentukan menurut dalam Tabel 1, penentuan nilai m (niai hubungan kedalaman dan kapasitas waduk) didasarkan pada hubungan kedalaman dan tampungan waduk seperti pada Gambar 2. Jika nilai $\mathrm{m}$ bervariasi maka dapat diambil nilai $m$ yang paling dominan.

Tabel 1. Bentuk Waduk dan Tipe Kurva

\begin{tabular}{|c|c|c|}
\hline Bentuk Waduk & Tipe Kurva & m \\
\hline Danau & I & $3,5-4,5$ \\
\hline Dataran - kaki bukit & II & $2,5-3,5$ \\
\hline Bukit - pegunungan & III & $1,5-2,5$ \\
\hline Pegunungan & IV & $1,0-1,5$ \\
\hline
\end{tabular}




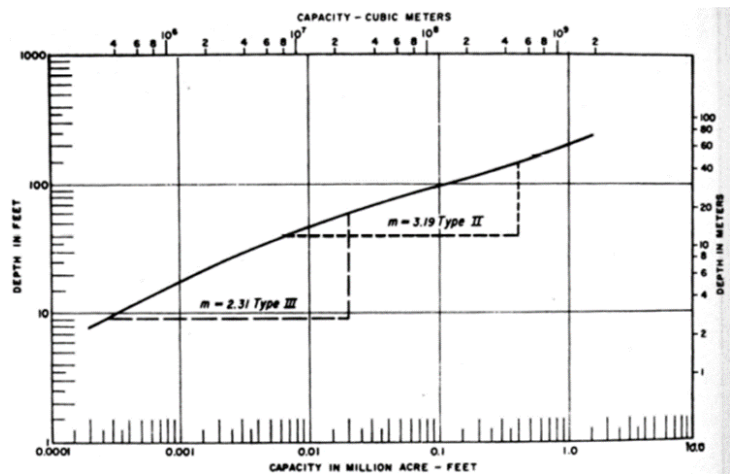

Gambar 2. Hubungan Kedalaman dan Tampungan Waduk

b. Sistem operasi waduk, ditentukan menurut Tabel 2.

Tabel 2. Bentuk Waduk dan Tipe Kurva

\begin{tabular}{|c|c|c|c|}
\hline Operasi waduk & $\begin{array}{c}\text { Tingkat } \\
\text { Operasional }\end{array}$ & Tipe & Tipe Kurva \\
\hline \multirow{3}{*}{$\begin{array}{l}\text { Sedimen terendam di } \\
\text { waduk }\end{array}$} & \multirow[t]{3}{*}{$\mathrm{I}$} & $\mathrm{I}$ & I \\
\hline & & II & I atau II \\
\hline & & III & II \\
\hline \multirow{3}{*}{$\begin{array}{l}\text { Surutan muka air } \\
\text { waduk sedang }\end{array}$} & \multirow[t]{3}{*}{ II } & $\mathrm{I}$ & I atau II \\
\hline & & II & II \\
\hline & & III & II atau III \\
\hline \multirow{3}{*}{$\begin{array}{l}\text { Surutan muka air } \\
\text { waduk cukup besar }\end{array}$} & \multirow[t]{3}{*}{ III } & $\mathrm{I}$ & II \\
\hline & & II & II atau III \\
\hline & & III & III \\
\hline $\begin{array}{l}\text { Dalam keadaan } \\
\text { normal waduk }\end{array}$ & IV & & IV \\
\hline
\end{tabular}

c. Ukuran butiran sedimen, ditentukan menurut Tabel 3.

Tabel 3. Ukuran Butiran Sedimen Waduk dan Tipe Kurva

\begin{tabular}{|c|c|}
\hline $\begin{array}{c}\text { Ukuran Butiran Sedimen yang } \\
\text { Dominan }\end{array}$ & Tipe \\
\hline Pasir atau material kasar & I \\
\hline Lanau & II \\
\hline Lempung & III \\
\hline
\end{tabular}

3. Menentukan kedalaman nol baru pada waduk dengan menentukan Fungsi tak berdimensi (F) tiap-tiap elevasi dengan Persamaan 2 (Morris \& Fan, 2010) :

$$
\mathrm{F}=\frac{\mathrm{S}-\mathrm{V}_{\mathrm{h}}}{\mathrm{H} \mathrm{A}_{\mathrm{h}}}
$$

Dimana $\mathrm{S}=$ total sedimen yang mengendap $\left(\mathrm{m}^{3}\right), \mathrm{H}=$ kedalaman waduk mula-mula $(\mathrm{m}), \mathrm{V}_{\mathrm{h}}=$ volume total waduk pada kedalaman elevasi $\mathrm{H}\left(\mathrm{m}^{3}\right), \mathrm{A}_{\mathrm{h}}=$ luas total waduk pada kedalaman elevasi $\mathrm{H}$ $\left(\mathrm{m}^{2}\right)$.

Nilai p (kedalaman relatif) dapat dihitung dengan Persamaan 3 (Morris \& Fan, 2010):

$$
\mathrm{p}=\frac{\mathrm{h}}{\mathrm{H}}
$$

Dimana $\mathrm{h}=$ kedalaman pada elevasi $\mathrm{H}$ (m) dan $\mathrm{H}=$ kedalaman total mula-mula (m).

Nilai $F$ dan $p$ di plot kedalam grafik seperti pada Gambar 3 untuk dicari perpotongannya dengak kurva yang ditentukan sebagai dasar penentuan elevasi nol waduk yang baru setelah Ttahun.

4. Mendistribusikan sedimen pada setiap kedalaman waduk berdasarkan kurva tipe waduk yang ditentukan dengan menghitung luas relatif (a) berdasarkan kedalaman relatif (p) menggunakan persamaan (Morris \& Fan, 2010) :

tipe I $\quad: a=5,047 p^{1,85}(1-p)^{0,36}$

tipe II $\quad: a=2,487 p^{0,57}(1-p)^{0,41}$

tipe III $\quad: a=16,967 p^{1,15}(1-p)^{2,32}$

tipe IV $\quad: a=1,486 p^{-0,25}(1-p)^{1,34}$

5. Menghitung luas terkoreksi dengan membagi luas tampungan awal pada elevasi nol baru dengan luas relatifnya.

6. Menghitung luas terdistribusi pada tiap elevasi dengan mengkalikan luas tampungan awal dengan luas terkoreksi pada point (e) untuk elevasi diatas nol baru.

7. Menghitung distribusi sedimen pada tiaptiap elevasi dengan Persamaan 4 (Morris \& Fan, 2010) :

$$
V_{s h}=\frac{a_{h}+a_{h h-1}}{2} \cdot \Delta h
$$

Dimana $\mathrm{V}_{\mathrm{sh}}=$ volume sedimen pada kedalaman $\mathrm{h}\left(\mathrm{m}^{3}\right), \mathrm{a}_{\mathrm{h}}=$ luas terdistribusi pada kedalaman $\mathrm{h}\left(\mathrm{m}^{2}\right), \mathrm{a}_{\mathrm{h}-1}=$ luas terdistribusi pada kedalaman $\mathrm{h}-1 \quad\left(\mathrm{~m}^{2}\right)$, $" \Delta \mathrm{h} "=$ selisih kedalaman (m).

8. Menghitung tampungan aktual waduk setelah T-tahun dengan mengurangi tampungan awal dengan distribusi sedimen pada tiap-tiap elevasi pada point (g) 


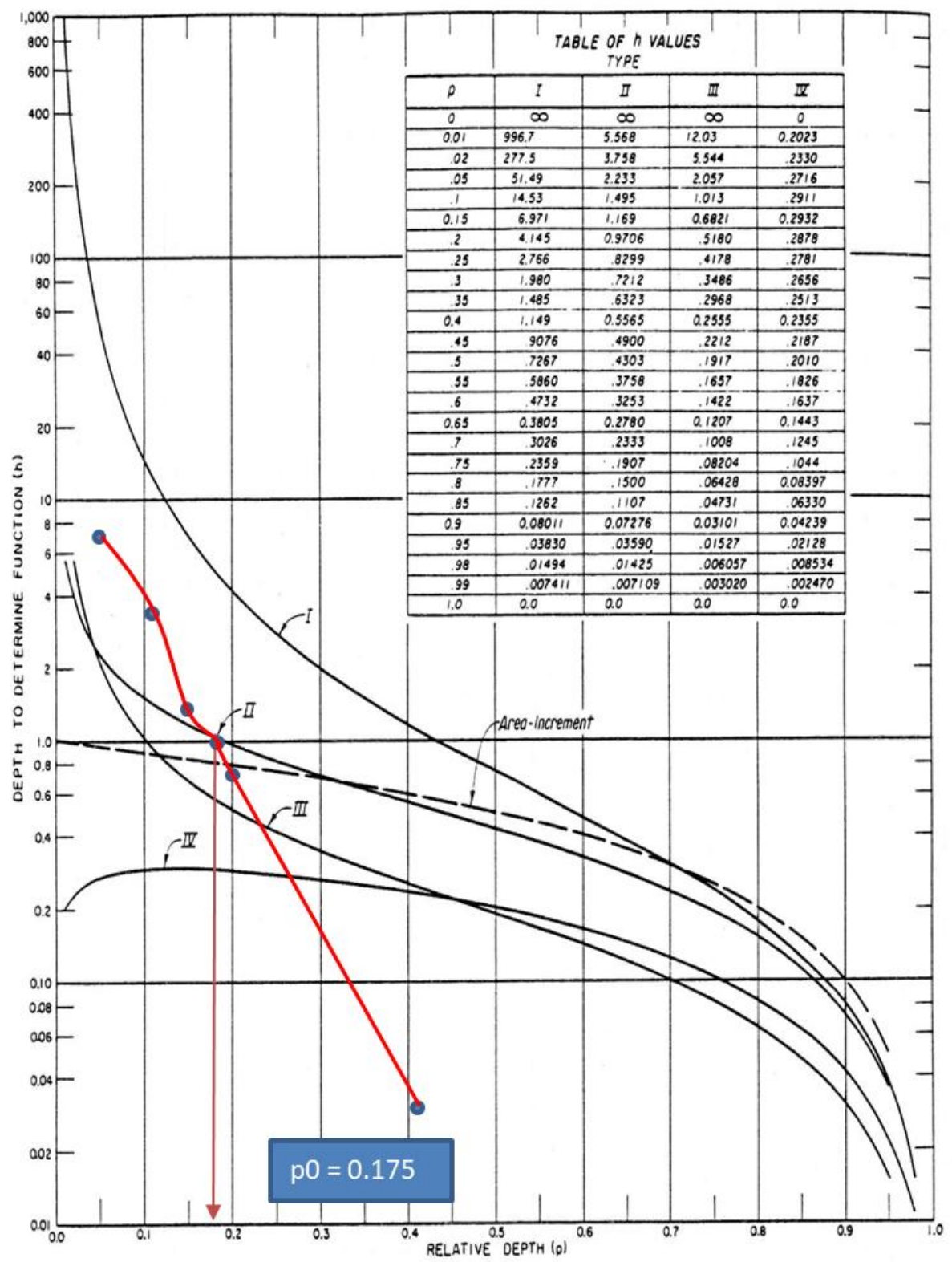

Gambar 3. Ploting Grafik Penentuan $p_{0}$ pada Waduk Tilong

\section{HASIL DAN PEMBAHASAN}

Analisis Sedimentasi (Echo Sounding)

Perhitungan volume sedimentasi total untuk Waduk Tilong periode tahun 20022015 dapat ditampilkan pada tabel 4. Dari perhitungan volume sedimentasi pada Waduk Tilong di atas didapatkan prediksi sedimentasi periode tahun 2002 sampai dengan 2015 adalah sebesar 3.060.231,99 $\mathrm{m}^{3}$.

\section{Distribusi Sedimen di Waduk}

Berdasarkan dari hasil perhitungan dengan Metode Empiris Pengurangan Luas diperoleh elevasi nol baru sedimen yang mengendap pada elevasi $+72,83 \mathrm{~m}$. Pada Waduk Tilong elevasi intake ada pada elevasi $+81,00$, sehingga dari hasil analisis distribusi elevasi nol baru waduk akibat sedimentasi selama tahun 2002-2015 masih dibawah elevasi ambang intake yang ada. Distribusi sedimen untuk tiap-tiap elevasi disajikan pada Tabel 5. Pada saat muka air normal, kapasitas volume total Waduk Tilong pada tahun 2002 19,07 juta $\mathrm{m}^{3}$ menjadi 16,47 juta $\mathrm{m}^{3}$ seperti yang terlihat pada Tabel 5 .

Tabel 4. Perhitungan Sedimentasi Pada Waduk Tilong Periode 2002-2015 
Vol. 3 No.2 Juni 2020

http://jurnal.umsb.ac.id/index.php/RANGTEKNIKJOURNAL

\begin{tabular}{|c|c|c|c|c|c|c|c|}
\hline \multirow{2}{*}{ No } & \multirow[b]{2}{*}{ Cross } & \multicolumn{2}{|r|}{ Luas $\mathrm{m}^{2}$} & \multirow{2}{*}{ Interval } & \multicolumn{2}{|c|}{ Volume $\mathbf{m}^{3}$} & \multirow{2}{*}{ Ket } \\
\hline & & Erosi & Sedimentasi & & Erosi & Sedimentasi & \\
\hline \multirow[t]{2}{*}{1} & Line 1 & 0 & $4,925.66$ & & & & \\
\hline & & & & 64.12 & 0 & $266,992.52$ & \\
\hline \multirow[t]{2}{*}{2} & Line 2 & 0 & $3,402.24$ & & & & \\
\hline & & & & 81.57 & 0 & $187,541.52$ & \\
\hline \multirow[t]{2}{*}{3} & Line 3 & 0 & $1,196.06$ & & & & \\
\hline & & & & 86.01 & 0 & $145,995.30$ & \\
\hline \multirow[t]{2}{*}{4} & Line 4 & 0 & $2,198.79$ & & & & \\
\hline & & & & 68.4 & 0 & $147,527.13$ & \\
\hline \multirow[t]{2}{*}{5} & Line 5 & 0 & $2,114.87$ & & & & \\
\hline & & & & 56.01 & 0 & $112,077.57$ & \\
\hline \multirow[t]{2}{*}{6} & Line 6 & 0 & $1,887.18$ & & & & \\
\hline & & & & 91.78 & 0 & $203,598.13$ & \\
\hline \multirow[t]{2}{*}{7} & Line 7 & 0 & $2,549.47$ & & & & \\
\hline & & & & 98.87 & 0 & $270,396.76$ & \\
\hline \multirow[t]{2}{*}{8} & Line 8 & 0 & $2,920.27$ & & & & \\
\hline & & & & 112.11 & 0 & $296,763.44$ & \\
\hline \multirow[t]{2}{*}{9} & Line 9 & 0 & $2,373.88$ & & & & \\
\hline & & & & 104.66 & 0 & $223,352.66$ & \\
\hline \multirow[t]{2}{*}{10} & Line 10 & 0 & $1,894.28$ & & & & \\
\hline & & & & 98.58 & 0 & $219,010.18$ & \\
\hline \multirow[t]{2}{*}{11} & Line 11 & 0 & $2,549.02$ & & & & \\
\hline & & & & 144.82 & 0 & $299,128.25$ & \\
\hline \multirow[t]{2}{*}{12} & Line 12 & 0 & $1,582.02$ & & & & \\
\hline & & & & 139.61 & 0 & $246,528.50$ & \\
\hline \multirow[t]{2}{*}{13} & Line 13 & 0 & $1,949.66$ & & & & \\
\hline & & & & 209.24 & 0 & $308,851.47$ & \\
\hline \multirow[t]{2}{*}{14} & Line 14 & 0 & $1,002.47$ & & & & \\
\hline & & & & 150.29 & 0 & $132,468.56$ & \\
\hline \multirow[t]{2}{*}{15} & Line 15 & 0 & 760.37 & & & & \\
\hline & & & & Jumlah & & $3,060,231.99$ & $\mathrm{~m}^{3}$ \\
\hline
\end{tabular}

Tabel 5. Distribusi Sedimen pada Tiap Elevasi pada Waduk Tilong Tahun 2002 - 2015

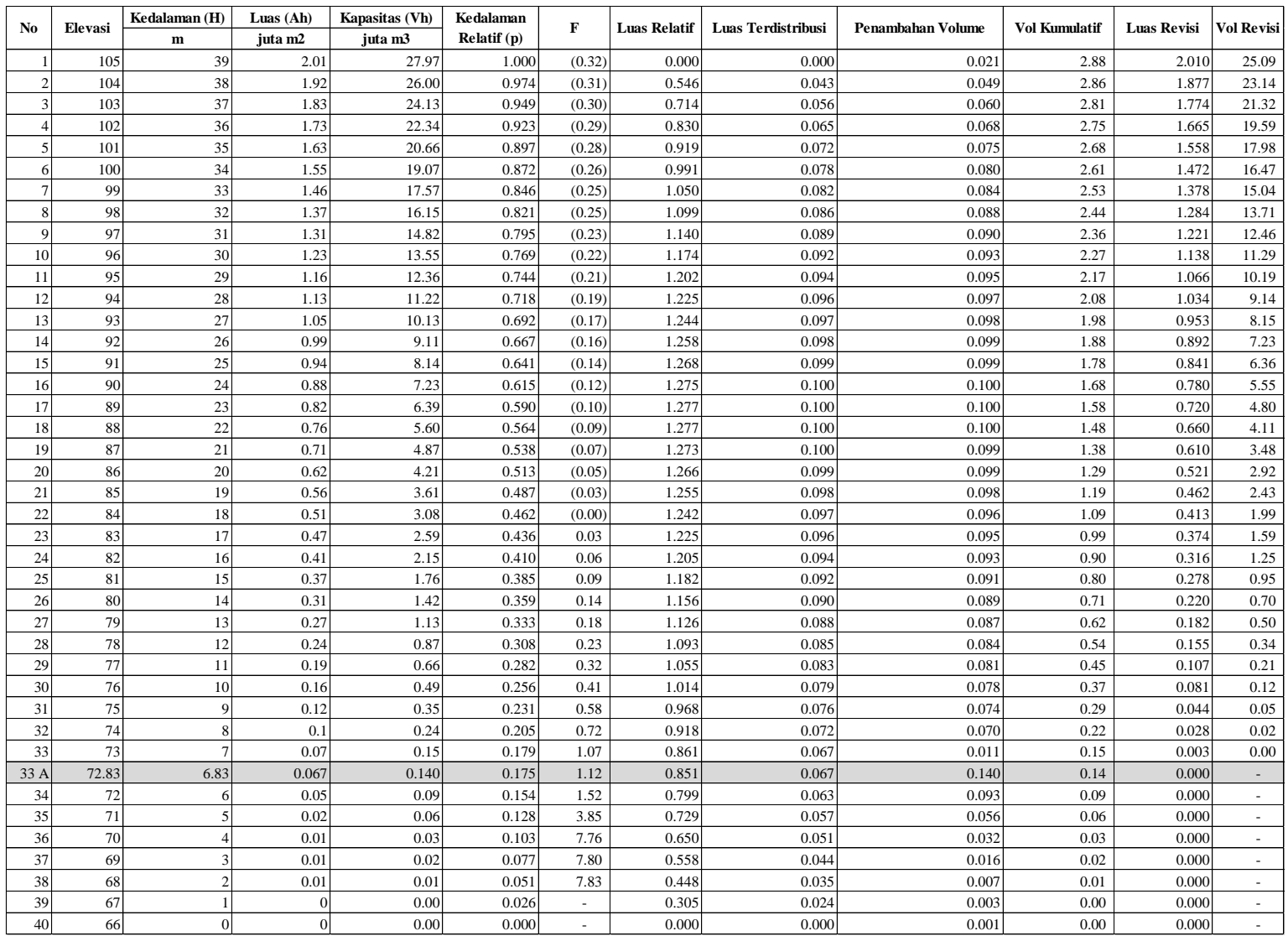


Berdasarkan hasil analisis distribusi sedimen untuk tiap-tiap elevasi diperoleh kurva lengkung kapasitas tampungan waduk untuk tahun awal operasi (2002) waduk dan tahun 2015, dan kurva lengkung luas tampungan yang disajikan dalam Gambar 4.

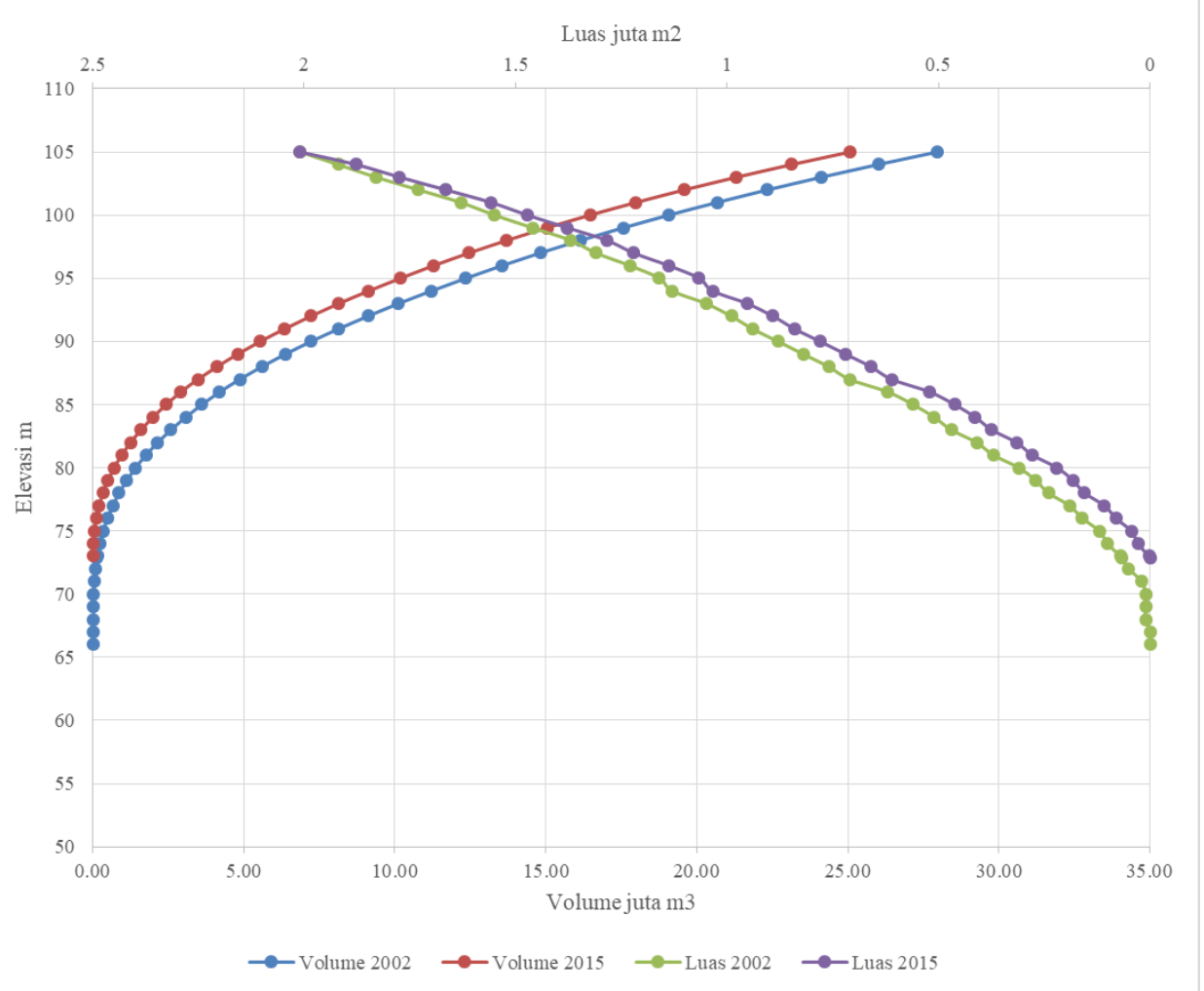

Gambar 4. Perbandingan Lengkung Kapasitas dan Luas Waduk Tilong Tahun 2002 dan 2015

Permasalahan sedimentasi di Waduk Tilong nantinya akan berdampak pada pengurangan usia operasi waduk. Oleh karena itu, Pemerintah telah memberikan acuan pengelolaan waduk dalam bentuk Pedoman Pengelolaan Sedimentasi Waduk. Dalam pedoman tersebut, kegiatan pengelolaan sedimentasi waduk dikelompokkan dalam 3 (tiga) kegiatan usaha (Mukhlisin, 2007) yaitu :

a. Meminimalkan beban sedimen yang masuk ke dalam waduk

Beberapa usaha yang dapat dilakukan antara lain :

- Pembangunan Cekdam disepanjang aliran Sungai Tilong.

- Perbaikan DAS dengan pendekatan sosial kemasyarakatan terkait pola tanam dalam berladang.

b. Meminimalkan jumlah sedimen yang mengendap (sedimentasi) di dalam waduk

c. Mengeluarkan endapan sedimen dari waduk

Beberapa usaha yang dapat dilakukan untuk mengeluarkan endapan sedimen dari waduk antara lain dengan flushing dan dredging.

\section{PENUTUP}

Mengacu pada hasil dan pembahasan yang telah diuraikan sebelumnya maka diperoleh kesimpulan berikut :

1) Volume sedimentasi di Waduk Tilong selama kurun waktu tahun 2002-2015 sebesar 3.060.231,99 $\mathrm{m}^{3}$.

2) Elevasi dasar waduk baru menggunakan metode empiris pengurangan luas untuk 2015 pada elevasi $+72,83 \mathrm{~m}$.

3) Kapasitas volume total waduk Tilong yang pada tahun 2015 adalah sebesar 16,47 juta $\mathrm{m}^{3}$ dari volume awal waduk di tahun 2002 adalah sebesar 19,07 juta $\mathrm{m}^{3}$ pada saat muka air normal.

\section{UCAPAN TERIMA KASIH}

Terima kasih kepada seluruh pihak yang telah membantu dalam penulisan hasil penelitian ini, terutama Balai Wilayah Sungai Nusa Tenggara II Kementerian PUPR.

$\begin{array}{lr}\text { Fakultas Teknik UMSB } & \text { ISSN 2599-2081 } \\ \text { EISSN 2599-2090 }\end{array}$




\section{DAFTAR PUSTAKA}

Balai Wilayah Sungai Nusa Tenggara II. (2015). Laporan Akhir Penyusunan Rencana Tindak Darurat Bendungan Tilong di Kabupaten Kupang. Kupang: Balai Wilayah Sungai Nusa Tenggara II Kementerian Pekerjaan Umum dan Perumahan Rakyat.

Direktorat Jendral Sumber Daya Air. (2009). Pedoman Konstruksi dan Bangunan Sipil, Survey dan Monitoring Sedimentasi Waduk. Jakarta: Departemen Pekerjaan Umum Direktorat Jendral Sumber Daya Air.

Issa, E. I., Al-Ansari, N., Sherwany, G., \& Knutsson, S. (2016). Evaluation and Modification of Some Empirical and Semi-empirical Approaches for Prediction of Area-Storage Capacity Curves in Reservoirs of Dams. International Journal of Sediment Research, 32(1), 127-135. https://doi.org/http://dx.doi.org/10.1016/j .ijsrc.2015.12.001

Morris, G. L., \& Fan, J. (2010). Reservoir Sedimentation Handbook. New York: McGraw-Hill Book Co.

Mukhlisin, M. (2007). Pengelolaan Sedimen Terpadu. Yogyakarta: Program Magister Pengelolaan Bencana Alam (MPBA) Universitas Gadjah Mada.

Tukaram, S., PT, N., \& MR, G. (2016). Comparison of area reduction method and area increment method for reservoir sedimentation distribution - Case study Ujjani dam. International Journal of Research in Advanced Engineering and Technology, 2(3), 108-111.

Wulandari, D. A. (2007). Penanganan Sedimentasi Waduk Mrica. Berkala Ilmiah Teknik Keairan, 13(4), 264-271.

WWS, A., \& Sundari, N. (2016). Studi Perubahan Volume Waduk Cacaban dengan Survei Pemeruman Waduk. Jurnal Teknik Pengairan, 7(2), 310-315. 